Connecticut College

Digital Commons @ Connecticut College

2009

\title{
Dispersal and establishment both limit colonization during primary succession on a glacier foreland
}

Chad C. Jones

Connecticut College, cjones8@conncoll.edu

Roger del Moral

Department of Biology, University of Washington

Follow this and additional works at: https://digitalcommons.conncoll.edu/botanyfacpub

Part of the Biology Commons, Botany Commons, Environmental Chemistry Commons, and the Organic Chemistry Commons

\section{Recommended Citation}

Jones, Chad C. and del Moral, Roger, "Dispersal and establishment both limit colonization during primary succession on a glacier foreland" (2009). Botany Faculty Publications. 3.

https://digitalcommons.conncoll.edu/botanyfacpub/3

This Article is brought to you for free and open access by the Botany Department at Digital Commons @ Connecticut College. It has been accepted for inclusion in Botany Faculty Publications by an authorized administrator of Digital Commons @ Connecticut College. For more information, please contact bpancier@conncoll.edu.

The views expressed in this paper are solely those of the author. 
Dispersal and establishment both limit colonization during primary succession on a glacier

\section{foreland}

Chad C. Jones ${ }^{1}$

Department of Biology

Box 355325

University of Washington

Seattle, WA 98195-5325

Roger del Moral

Department of Biology

Box 355325

University of Washington

Seattle, WA 98195-5325

${ }^{1}$ Author for correspondence: Current Address: Department of Botany, Connecticut College, 270 Mohegan Avenue, New London, CT 06320. Email: chad.jones@conncoll.edu Phone: 1-860-4395304 Fax: 1-860-439-2519. 


\section{Abstract}

Plant colonization can be limited by lack of seeds or by factors that reduce establishment. The role of seed limitation in community assembly is being increasingly recognized, but in early primary succession, establishment failure is still considered more important. We studied the factors limiting colonization on the foreland of Coleman Glacier, Washington, USA to determine the importance of seed and establishment limitation during primary succession. We also evaluated the effects of seed predation, drought and existing vegetation on establishment. We planted seeds of seven species into plots of four different ages and found evidence that both seed and establishment limitation are strong in early succession. We also found that seed and establishment limitation both remained high in later stages of succession. Seed predation reduced establishment for most species and some evidence suggested that drought and existing vegetation also limit establishment. Because both dispersal and establishment failure restrict colonization in recently exposed habitat, late-seral forest species may have a difficult time migrating upward in response to global climate change.

Keywords: competition, facilitation, seed limitation, seedling establishment 


\section{Introduction}

Colonization is critical to the development of vegetation after disturbance (Bazzaz 1979). In primary succession, many species fail to colonize disturbed areas for decades after the disturbance (Wood and del Moral 1987; del Moral and Eckert 2005). Such failures may be due either to seed limitation or to limitations on establishment (Turnbull et al. 2000; Clark et al. 2007).

Understanding the factors that limit colonization of glacial forelands is particularly important in view of the impacts of global warming. Globally, glaciers have been shrinking over the past 150 years at increasing rates (Hodge et al. 1998; Dyurgerov and Meier 2000). Some evidence suggests that alpine species distributions (Walther et al. 2005) and tree lines (Peterson 1994) are shifting upward. Therefore, many species must colonize newly exposed habitats if they are to shift upward in response to global warming. Understanding the importance of seed and establishment limitation on glacier forelands will provide insights into the ability of species to colonize newly exposed areas.

Successional theory states that late-seral species are prevented from colonizing young surfaces by stressful environmental conditions (Clements 1916; Connell and Slatyer 1977), implying that in early-successional habitats, colonization is limited by lack of establishment (Matthews 1992). In particular, drought and soil infertility can limit colonization in early primary succession (Titus and del Moral 1998; Jumpponen et al. 1999; Lichter 2000). This view holds that late-seral species can establish only after physical amelioration or biotic facilitation of the site. Davidson (1993) hypothesized that seed predation also reduces colonization of late-seral species in the early stages of succession, thus slowing succession. Limits on establishment may 
restrict early colonization to favorable microsites such as cracks and depressions (Jones and del Moral 2005a).

However, it has become increasing apparent that seed limitation is common in plant communities (Turnbull et al. 2000), even in extreme environments during early primary succession (Chapin et al. 1994) or at high elevations (Eskelinen and Virtanen 2005; Lindgren et al. 2007). Seed limitation can result from poor dispersal (Primack and Miao 1992) or limited seed production (Clark et al. 2007). In early succession, seed limitation of late-seral species is likely due to lack of dispersal from other sites, since no reproductive individuals are present.

Later in succession, species may still be seed limited, although seed limitation is thought to be less common than in early succession (Turnbull et al. 2000). Alternatively, in late succession species establishment may be limited by competition (Chapin et al. 1994). Microsites with reduced competition or with greater available light can support increased colonization or survival (Eriksson and Ehrlén 1992; Oswald and Neuenschwander 1993).

Seed and establishment limitations may interact to delay colonization (Eskelinen and Virtanen 2005; Clark et al. 2007). The few studies that have experimentally studied colonization limitation on glacier forelands have found a combination of seed and establishment limitation (Chapin et al. 1994; Niederfriniger Schlag and Erschbamer 2000). However, these studies have focused on dominant canopy species or early successional species. No other studies have examined the factors that limit colonization by forest understory species in newly deglaciated terrain.

In this study, we examined the factors that limit colonization in four terrain age classes on the foreland of Coleman Glacier, Washington, USA. We studied species with different life histories and with peak abundances at different age classes, thus providing a comprehensive 
overview of colonization during primary succession in this system. We addressed three questions: 1) To what extent are seed limitation and establishment limitation important during primary succession? 2) Does the importance of these two factors change during succession? 3) What specific factors limit establishment of seeds reaching potential germination sites? We expected that both seed and establishment limitation would decrease through succession as vegetation developed and environmental conditions were ameliorated.

\section{Materials and methods}

Study site

Coleman Glacier is on the northwest side of Mount Baker in northwestern Washington State ( $\mathrm{N} 48^{\circ} 48^{\prime}$, W $121^{\circ} 51^{\prime}$ ). The foreland occurs in the transition between the Abies amabilis and Tsuga mertensiana forest zones (Franklin and Dyrness 1988; plant nomenclature follows Kartesz 1999). Average annual precipitation at this site was estimated at $292 \mathrm{~cm}$ (based on the PRISM model of Daly et al. 1994), but only $16 \%$ of this falls during the growing season (JuneSeptember).

The glacier terminus has retreated more than $2 \mathrm{~km}$ since 1823, from an elevation of $\sim 900 \mathrm{~m}$ (Heikkinen 1984) to the current elevation of $~ 1300 \mathrm{~m}$ above sea level. A moraine from the early sixteenth century is within meters of the 1823 moraine so the surface beyond this point has not been covered by ice for at least 500 years.

We divided the foreland into three age classes based on time since deglaciation: Age Class I $=0-24$ years, Age Class II $\approx 70-95$ years, and Age Class III $\approx 150-180$ years (Fig. 1 ). These 
classes were bounded by dated moraines deposited in 1979, 1908, and $\sim 1823$. These moraines were dated based on the average age of 12-18 largest trees on each (Heikkinen 1984). A fourth age class consisted of terrain outside the foreland but within $250 \mathrm{~m}$ of the moraine from the early sixteenth century (see Jones and del Moral 2005b).

Age Class I consisted of rocky bare mineral soil and $~ 25 \%$ vegetation cover (Jones and del Moral 2005b). Vegetation consisted predominantly of small ( $<2 \mathrm{~m})$ shrubs of Alnus viridis and Salix sitchensis mixed with herbaceous perennials, such as Chamerion latifolium, and seedlings of several conifer species. Many individual plants in this age class were growing in depressions or next to rocks, which are common in this age class (Jones and del Moral 2005a). Age Class II was dominated by a dense canopy of Alnus viridis (ca. 3-5 m in height) with an understory of the shrubs Sambucus racemosa and Ribes lacustre, a variety of herbaceous perennials, and scattered conifer saplings. The mineral soil was covered by a thin $(<10 \mathrm{~cm})$ organic horizon. Age Class III was dominated by a dense canopy of Tsuga heterophylla and Abies amabilis ( $>15 \mathrm{~m}$ in height). The understory was sparse, dominated by mosses such as Rhytidiopsis robusta, several fern species, and herbaceous perennials such as Tiarella trifoliata. Beyond the foreland, Age Class IV had an open conifer canopy (ca. 65\% canopy cover). Understory shrubs, such as Rubus spectabilis and Vaccinium ovalifolium, were more common and mosses less common than in Age Class III. These mature forests were also present on ridges above the younger age classes; no point on the foreland was more than $500 \mathrm{~m}$ from forests in Age Class IV. The soils in both Age Class III and IV are covered by an organic horizon of up to $30 \mathrm{~cm}$.

Various granivores and herbivores occur in this area. Granivorous small mammals include Tamiasciurus douglasii (Douglas’ squirrel), Tamias townsendii (Townsend's chipmunk) and Peromyscus keeni (northwestern deer mouse; Cassidy et al. 1997; mammal nomenclature follows 
Wilson and Reeder 2005). Several species of voles (Microtus spp.) are also common, but these eat vegetative parts rather than seeds. Several species of birds that feed primarily on seeds, including Junco hyemalis (dark-eyed junco), Carduelis pinus (pine siskin) and Loxia curvirostra (red crossbill) also are common in this habitat (Cassidy et al. 1997; bird nomenclature follows American Ornithologists' Union 1998). Odocoileus hemionus (mule deer) and Oreamnos americanus (mountain goat) are large herbivores that frequent this area.

Field methods

During late summer 2000, we collected seeds of six common species from the area immediately surrounding the foreland of Coleman Glacier. Species were classified as pioneers, mid-seral, late-seral, or present in all stages (Table 1) based on our earlier studies (Jones 2003; Jones and del Moral 2005b). Species were chosen based on abundance and to represent all stages of succession. Seeds were cleaned and separated into groups of 100. We could not collect sufficient numbers of seeds of Tiarella trifoliata at the foreland, so we purchased additional regionally collected seeds of this species from Inside Passage of Port Townsend, Washington. Many of these species require cold stratification or other treatment for germination (Young and Young 1992; Rose et al. 1998, B.A. Selemon, University of Washington, personal communication) and were treated as necessary prior to planting (Table 1). Seeds were planted in five sets of paired 1-m² plots in each age class in early July 2001 (July plots), shortly after snow melt. We randomly placed the plots within a 1 ha area in each of the four age classes. One of each pair was surrounded by a hardware cloth $(1 \mathrm{~cm}$ mesh) exclosure $55 \mathrm{~cm}$ high and buried 5$10 \mathrm{~cm}$ into the ground to prevent seed predation by small mammals. The other plot, located $<1 \mathrm{~m}$ 
away, had no exclosure (open plot). Each plot was divided into a grid of 16, 20 x $20 \mathrm{~cm}$ subplots. This 80 x $80 \mathrm{~cm}$ grid was surrounded by a 10cm wide buffer. Each species was assigned randomly to one subplot per plot. One hundred seeds of the species were placed on the surface within the assigned subplot. The ground surface was then brushed lightly to enable seeds to settle to the surface. One additional subplot was identified as an unseeded control. Plots were monitored every four weeks through September. Numbers of seedlings were counted in each subplot, including the control.

During the summer, we collected additional seeds and in October 2001, we established 10 additional pairs of plots in Age Classes I, III, and IV (October plots) to increase the sample size. An August flood changed the stream course and prevented access to Age Class II during October. For the October plots, we added Vaccinium ovalifolium to increase the representation of late-seral species (Table 1). We did not have sufficient seeds of Tiarella so it was not included in plots from Age Class III. The seeds planted in October were not pretreated, but were exposed to natural conditions over the winter.

During summer 2002, we counted seedlings at four 4-week intervals from July 3 to September 25. Surviving seedlings were again counted in early July 2003. We also measured environmental variables that might impact seedling germination and establishment. In late July 2002, we estimated the cover of each species in each $1-\mathrm{m}^{2}$ plot. Individuals taller than $2 \mathrm{~m}$ were not included in these cover measurements, but we estimated (to the nearest 10\%) the aggregate cover of all individuals $>2 \mathrm{~m}$ (canopy cover). We also recorded the elevation, aspect, and slope of each plot. Measurements of slope and aspect were combined with latitude to estimate potential heat load for each plot (McCune and Keon 2002); potential heat load is highest in southwestfacing plots with slope equal to latitude. 
We collected a soil sample immediately outside each plot in late August 2002 after more than 1 week without rain. Loose litter and debris were removed and the sample was taken from a depth of 0-10 cm. In Age Class I there was no organic horizon, in Age Class II the organic horizon was $<10 \mathrm{~cm}$, and in Age Classes III an IV the organic horizon was $>10 \mathrm{~cm}$, thus soils varied greatly among age classes. Soil samples were sealed and weighed upon return to the laboratory. Soils were dried for 48 hours at $105^{\circ} \mathrm{C}$ to determine percent moisture content by mass. Soil organic matter content was determined using a loss-on-ignition test at $610^{\circ} \mathrm{C}$ in a muffle furnace. Soil pH was measured using a 1:1 soil paste with a VWR Products pHastchek $^{\mathrm{TM}}$ $\mathrm{pH}$ meter.

Statistical analysis

To analyze the effects of seeding, exclosures and age class on the numbers of seedling in each plot, we ran generalized linear mixed models (GLMM) for each species using the 'Ime4' package (Bates et al. 2008) in R (R Development Core Team 2008). Because patterns were so different between the two planting times we analyzed July and October plots separately. We used plot (consisting of the seeded and control subplots in both the paired exclosure and open plots) as a random effect, and seeding, exclosure, and age class as fixed effects. Age class was converted to dichotomous dummy variables. The response variable was the greatest number of seedlings in the subplot at any sample date. We included all main effects and two-way interactions in each model. We then simplified the models beginning with interaction terms using Akaike’s Information Criterion (AIC). Variables that increased AIC when present were removed from the model (Crawley 2002). Parameter estimates were calculated for each variable retained in the 
simplified model and significance of each parameter was tested using the Wald statistic (Bates et al. 2008). However, when parameter estimates are large, the Wald statistic is biased (Menard 2002). For variables with large parameter estimates $(>10)$ we determined significance by creating models with and without the variable and comparing the two models using ANOVA (Crawley 2002).

Variation in topography, vegetation cover, and soils can also affect establishment. For each age class we calculated Spearman rank correlations using Statistix 7.0 (Analytical Software 2001) between numbers of seedlings of each species and the topographic (elevation, slope, and heat load), vegetation (understory cover, canopy cover), and soil (\% soil moisture, \% organic matter, and soil $\mathrm{pH}$ ) variables measured for each plot. Both exclosure and open plots from both planting times were combined to calculate these correlations.

We calculated the relative seed limitation (RSL) and fundamental establishment limitation (FEL) for each species in each age class (Nathan and Muller-Landau 2000). RSL represents the degree of seed limitation given the existing establishment conditions and is calculated as (1 density in control plots / density in seed plots). FEL represents the degree of establishment limitation in the absence of seed limitation and is calculated as (1 - mean density in seed plots / maximum density in seed plots). Although these measures cannot directly be compared to each other, they do allow us to compare each limiting factor among species and age classes.

To describe edaphic and environmental differences among age classes, we summarized and compared topographical, vegetation, and soil variables among age classes using Kruskal-Wallis tests followed by comparison of ranks in Statistix 7.0 (Analytical Software 2001). True replication of age classes was not possible given the spatial pattern of glacial retreat, thus environmental factors may vary among age classes due to both spatial patterns and successional 
age. For example, elevation decreases with distance from the glacier terminus, so Age Classes III and IV are mostly at lower elevations than Age Classes I and II.

\section{Results}

During winter 2001-02, the glacier advanced almost $50 \mathrm{~m}$, although it has since retreated. The advancing glacier, falling ice, and changing stream channels destroyed many plots in Age Class I. Only one paired plot remained from the July planting. From the October planting, two paired plots and four additional plots without exclosures remained.

Very few seedlings germinated in the July plots during the first summer (2001). More seedlings were present in 2002 and 2003, thus data from these years were used. Numbers of seedlings per plot were much higher in July plots than October plots for Ribes lacustre, Rubus spectabilis and Tiarella trifoliata $(\mathrm{Z} \geq 2.86, \mathrm{P} \leq 0.004)$, but not for Abies amabilis, Chamerion latifolium, or Sambucus racemosa $(Z \leq 1.00, P \geq 0.32)$. Numbers of seedlings for most species decreased through time in July plots due to mortality (Supplement S1). In October plots numbers of seedlings declined through time for Abies, Chamerion, and Tiarella, but for Rubus, Ribes, and Vaccinium numbers of seedlings increased over time as more seeds germinated.

Seed limitation

The generalized linear mixed models showed that addition of seeds significantly increased the number of seedlings for all species except Abies and Chamerion in the July plots (Table 2, Fig. 2) and Abies in the October plots (Table 3, Fig. 3). Age class affected the number of seedlings for several species, but not always consistently between July and October plots (Figs. 
2-3). Abies had more seedlings in Age Classes I and III as did Ribes in Age Class I. Numbers of seedlings of the late-seral species were lower in early succession for Rubus and Tiarella in the July plots and for Vaccinium in the October plots. However, both Rubus and Tiarella had high, but variable, numbers of seedlings in Age Class I in the October plots. There were few seedlings of Chamerion or Sambucus in any age class (with the exception of Age Class III in the October plots for Chamerion).

Realized seed limitation (RSL) was generally high for all species and in all age classes (Fig. 4). Although RSL was lowest for all species in age classes where the species is most common, it was still high in these age classes for Rubus, Ribes, Tiarella, and Vaccinium. RSL was low for Abies in Age Class IV and there was no evidence of realized seed limitation for Chamerion in Age Class I. RSL could not be calculated for Chamerion in Age Class II or Vaccinium in Age Classes I or II because of lack of germination.

Establishment limitation

Fundamental establishment limitation (FEL) was also generally high (Fig. 5). It was lowest for Abies and Chamerion in Age Class I, for Ribes and Rubus in Age Class II and for Tiarella and Vaccinium in Age Class III. In no case was FEL highest in early succession.

The GLMM models showed that exclosures affected the number of seedlings in plots for most species. Although the main effect for exclosure was not significant for any species in the July plots (Table 2), there was a positive interaction for Abies and Rubus in Age Classes II and III and for Tiarella in Age Class II. There were many more seedlings of Ribes outside of exclosures in Age Class I but this was based on a single paired plot. In the October plots, exclosures had a positive effect on number of seedlings for Abies, Ribes, Rubus and Vaccinium 
and a negative effect for Tiarella (Table 3). In Age Class I, however, both Abies and Ribes had more seedlings in open plots (Fig. 3). The impact of exclosures is particularly strong for Abies. The average number of seedlings in seeded exclosure plots of all age classes (3.66) was almost three times greater than in seeded open plots (1.29).

Many of the exclosures in all age classes were damaged or removed during the first winter by snow or by high winds. However, all of these exclosures were in place during fall, which would have provided protection when the seeds were most susceptible to predators. After snowfall and in the spring, seeds of most species are much more difficult for predators to find. If anything, this damage would reduce the effect of exclosures, thus making our results a conservative estimate.

Several plot variables were correlated with seedling number in seeded plots (Table 4). Elevation was negatively correlated with number of seedlings for one species in each of Age Classes II, III and IV while heat load was negatively correlated to the number of Rubus seedlings in Age Class I. Both understory and canopy cover were negatively correlated with several species in late succession. Soil pH was positively and organic matter negatively correlated with several species throughout the successional sequence.

Variation in environmental variables among age classes

Most environmental variables differed significantly among age classes (Supplement S2). Elevations of plots in Age Classes I and II were higher than those in Age Classes III and IV. Plots in Age Class I were steeper than those in Age Class II, but the range of mean slopes was low (3-9 degrees). Soil moisture and organic matter were higher in older age classes (III and IV), 
while $\mathrm{pH}$ tended to be lower. Both understory ( $<2 \mathrm{~m})$ and canopy $(>2 \mathrm{~m})$ cover were low in Age Class I and much higher in the other age classes. Species richness was lowest in Age Class III. Litter was highest in Age Classes II and IV.

\section{Discussion}

Seed and establishment limitation through succession

Lack of available seeds and failure to establish combined to limit colonization in both early and late succession. Adding seeds increased numbers of seedlings for almost all species, but seedling numbers remained low. The indices for both seed and establishment limitation were consistently high. Chapin et al. (1994) also found evidence of both forms of limitation on a very large foreland. These results show that even on this small foreland, with proximate seed sources, seed and establishment limitation both restrict colonization.

Seed and establishment limitation have often been viewed as mutually exclusive, with limits to establishment considered to be much more important in restricting colonization on glacier forelands (Matthews 1992). More recently there has been an emphasis in determining the prevalence of seed limitation in plant populations (Turnbull et al. 2000). However, it is increasingly recognized that both effects are often prominent in a community (Clark et al. 2007). This study suggests that dispersal and establishment are multiple sieves that limit colonization. Even if a few seeds of late-seral species reach an early successional site, they often fail to lodge in suitable microsites. Thus, even if seed limitation were reduced at this site, the high fundamental establishment limitation suggests that colonization would remain limited. 
In early succession, one mid- and two late-seral species (Ribes, Rubus, and Tiarella) showed strong evidence of seed limitation. These species never occurred naturally in early succession (Age Class I), but were fairly common in older communities only a few hundred meters distant (Jones and del Moral 2005b). This suggests that limited dispersal precludes these species from colonizing soon after glacial retreat. These mid- and late-seral species are dispersed by animals (Ribes and Rubus, Haeussler et al. 1990) or have no apparent mechanism for dispersal (Tiarella, Alaback and Herman 1988) so they may not be as readily dispersed into open primary successional areas that are dominated by wind dispersed species. The pioneer species Chamerion is wind dispersed (C.C. Jones, personal observation) and showed no evidence of seed limitation in early succession.

Establishment limitation also played an important role in limiting colonization in early succession. Vaccinium did not germinate even when planted. When mid- and late-seral species (e.g. Ribes and Rubus) did germinate at this stage, they appeared to be restricted to specific microsites, such as cracks or other sheltered areas (C.C. Jones, personal observation). Several studies of early primary succession have shown that seedlings are associated with specific microsites (Titus and del Moral 1998; Jones and del Moral 2005a).

Seed limitation for late-seral species was lower in late succession. All species had the lowest realized seed limitation in age classes where they naturally occurred as reproductive adults (Fig. 4). However, seed limitation of most species was high even in these areas near reproductive individuals. The two exceptions, Chamerion and Abies, produce copious quantities of seed and naturally occurring seedlings were common in age classes with reproductive adults (Jones and del Moral 2005a). 
Establishment limitation was lower in early succession than late succession for most species (Fig. 5). We expected establishment limitation to be highest in early succession because of drought and temperature stresses common to glacier forelands (Matthews 1992; Jumpponen et al. 1999). Despite considerable soil development and increased canopy cover which potentially reduced temperature extremes and drought, factors such as competition (Chapin et al. 1994) limited establishment in late succession. Stevens et al. (2004) found that increasing soil fertility can lead to an increase in establishment limitation due to competition. Thus, as succession proceeds, the factors limiting establishment may change without strongly affecting the degree of establishment limitation.

Factors that limit establishment

Seed predation helped limit establishment of several species (Fig. 2-3). The species with the largest seeds (Abies, Ribes and Rubus) showed the strongest effect, suggesting that larger seeded species are more susceptible to predation (although the small seeded Vaccinium was also affected). Seed predation did not play a significant role on the small seeded Tiarella (Tappeiner and Alaback 1989). Selective seed predation can lead to large changes in community composition (Howe and Brown 2000; Maron and Simms 2001). Since later successional species at this site tend to have larger seeds (Jones 2003), selective predation on these seeds may limit their colonization, thus slowing succession (Reader 1997).

It is important to recognize that other factors may have contributed to the difference in seedling numbers between exclosure and open plots. The exclosures themselves may have modified the microclimate through increased shading or reduced wind speed. In addition, the 
exclosures excluded small mammal herbivores (e.g. Microtus spp.) which might have influenced vegetation cover in the plots. We also acknowledge that these results probably overstate the effect of seed predation. Seeds were concentrated at high densities, potentially encouraging greater levels of predation than would occur naturally. However, we found partially eaten seeds of Abies and Rubus in the open plots in all age classes, suggesting that seed predation was important, at least for the large seeded species. We also found no differences in any plot variables (e.g. vegetation cover, soil properties, topography) between paired exclosure and open plots (C.C. Jones, unpublished data).

The importance of seed predation may change through succession. Our results suggest that seed predation was particularly strong in intermediate stages of succession (Age Classes II and III). There is less evidence for seed predation in early succession, as many species had more seedlings in open plots than in exclosures. However, because of the small number of surviving plots in this age class, we cannot make strong conclusions. Clearly some seed predation occurred in early succession because partially eaten seeds were found. Large-seeded conifer species often face heavy seed predation even in early primary succession (Lichter 2000).

Drought has been shown to reduce establishment in early primary succession on glacier forelands (Jumpponen et al. 1999), sand dunes (Lichter 2000), and volcanoes (Titus and del Moral 1998). We found little evidence that drought limited colonization at this site. Soil moisture was not correlated with seedling number for any species. However, topographical variation, even on the scale of a few meters may influence moisture conditions (Matthews and Whittaker 1987). Numbers of Rubus seedlings were negatively correlated with heat load. Several species were negatively correlated with elevation, even though elevation usually only varied by $<15 \mathrm{~m}$ among plots within an age class. Experiments and measurements of moisture throughout the growing 
season are necessary to better understand the role of drought in reducing establishment at this site.

The presence of existing vegetation was negatively correlated with numbers of seedlings of several species in late succession. However, there is a complex relationship between existing vegetation and plant colonization during succession. Existing vegetation can have a net positive effect (facilitation) or a net negative effect (inhibition) on colonization (Walker and del Moral 2003) and the effect of vegetation on colonization varies by species and by successional stage. Previous work at this site has shown that naturally occurring seedlings of Abies amabilis in early succession are more common where plant cover is high (Jones and del Moral 2005a). However, even in early primary succession, facilitative effects can be masked by inhibitive effects or may only be apparent after the death of the existing individuals (del Moral and Wood 1993; Chapin et al. 1994; Jumpponen et al. 1998). Later in succession, competition becomes more important than amelioration of environmental stress which may lead to a negative relationship between understory cover and colonization (Walker and Chapin 1987; Eriksson and Ehrlén 1992).

Although seed predation plays a strong role in limiting establishment at this site, the role of drought and existing vegetation is less certain. Other unmeasured factors, such as soil nutrient availability or extremes in temperature and moisture availability, may also play a role. Further experiments are necessary to tease apart the factors that limit establishment during primary succession. It is clear, however, that establishment is limited by the combination of several factors and that their effects can vary tremendously by species.

Implications for species response to climate change 
The rise of global temperatures is having major impacts on subalpine and alpine plant communities. Glaciers and ice fields are melting both in northwestern North America (Hodge et al. 1998) and throughout the world (Dyurgerov and Meier 2000), creating additional habitat for colonization by alpine and subalpine species. In addition, as climate warms, species are beginning to respond by shifting their distributions upward (Grabherr et al. 1994). However, the ability of most species to migrate and colonize these new sites remains uncertain (Beniston 2003).

Results from this study have important implications about the ability of forest species to migrate in response to climate change. It is clear from this study that both lack of dispersal and low germination rates combine to reduce colonization. These results corroborate other recent studies of high elevation habitats showing that both seed and microsite limitation are important in montane communities (Eskelinen and Virtanen 2005; Lindgren et al. 2007). Models for the Pacific Northwest predict that the tree line could shift upwards by as much as $600 \mathrm{~m}$ in response to increasing temperatures (Zolbrod and Peterson 1999). Our results suggest, however, that it may be difficult for many late-seral subalpine forest species to migrate upwards in response to climate change. Poor seed dispersal will limit the number of seeds that arrive in areas newly exposed by melting ice. Even those seeds that do arrive are unlikely to find suitable microsites and seedlings may perish from competition from established plants. The high degree of seed limitation even in late succession suggests that even as tree lines shift upwards, understory species may be slow to follow.

\section{Acknowledgements}


We thank L. Bair, J. Cousins, E. Jones, K. Jones, T. Jones and R. Wood for assistance with fieldwork. J. Boyd, M. Groom and C. Halpern and two anonymous reviewers provided valuable feedback on drafts of this manuscript. Funding was provided by the Mazamas and the Washington Native Plant Society. We thank the staff at the Mount Baker Ranger District for permission to conduct this research.

\section{References}

Alaback PB, Herman FR (1988) Long-term response of understory vegetation to stand density in Picea-Tsuga forests. Can J For Res 18:1522-1530

American Ornithologists' Union (1998) Check-list of North American birds, 7th edn. American Ornithologists' Union, Washington, D.C., USA

Analytical Software (2001) Statistix 7 User's Manual. Tallahassee, Florida, USA

Bates D, Maechler M, Dai B (2008) lme4: Linear mixed-effects models using S4 classes. Version 0.999375-28. http://cran.r-project.org

Bazzaz FA (1979) The physiological ecology of plant succession. Annu Rev Ecol Syst $10: 351-371$

Beniston M (2003) Climatic change in mountain regions: A review of possible impacts. Climatic Chang 59:5-31

Cassidy KM, Grue CE, Smith MR, Dvornich KM (eds) (1997) Washington State gap analysis - final report. Washington Cooperative Fish and Wildlife Research Unit, University of Washington, Seattle, Washington, USA, Vol 1-5

Chapin FS, Walker LR, Fastie CL, Sharman LC (1994) Mechanisms of primary succession following deglaciation at Glacier Bay, Alaska. Ecol Monogr 64:149-175 
Clark CJ, Poulsen JR, Levey DJ, Osenberg CW (2007) Are plant populations seed limited? A critique and meta-analysis of seed addition experiments. Am Nat 170:128-142

Clements FE (1916) Plant succession: an analysis of the development of vegetation. Carnegie Institution of Washington Publication 242

Connell JH, Slatyer RO (1977) Mechanisms of succession in natural communities and their role in community stability and organization. Am Nat 111:1119-1144

Crawley MJ (2002) Statistical computing: an introduction to data analysis using S-plus. John Wiley \& Sons, Chichester, UK

Daly C, Neilson RP, Phillips DL (1994) A statistical-topographic model for mapping climatological precipitation over mountainous terrain. J Appl Meteorol 33:140-158

Davidson DW (1993) The effects of herbivory and granivory on terrestrial plant succession. Oikos 68:23-35

del Moral R, Eckert AJ (2005) Colonization of volcanic deserts from productive patches. Am J Bot 92:27-36

del Moral R, Wood DM (1993) Early primary succession on the volcano Mount St. Helens. J Veg Sci 4:223-234

Dyurgerov MB, Meier MF (2000) Twentieth century climate change: Evidence from small glaciers. Proc Nat Acad Sci USA 97:1406-1411

Eriksson O, Ehrlén J (1992) Seed and microsite limitation of recruitment in plant populations. Oecologia 91:360-364

Eskelinen A, Virtanen R (2005) Local and regional processes in low-productive mountain plant communities: the roles of seed and microsite limitation in relation to grazing. Oikos 110:360-368 
Franklin JF, Dyrness CT (1988) Natural vegetation of Oregon and Washington. Oregon State University Press, Corvallis, Oregon, USA

Grabherr G, Gottfried M, Pauli H (1994) Climate effects on mountain plants. Nature $369: 448-448$

Haeussler S, Coates D, Mather. J (1990) Autecology of common plants in British Columbia: A literature review. B.C. Ministry of Forests, Victoria, Canada

Heikkinen O (1984) Dendrochronological evidence of variations of Coleman Glacier, Mount Baker, Washington, U.S.A. Arct Alp Res 16:53-64

Hodge SM, Trabant DC, Krimmel RM, Heinrichs TA, March RS, Josberger EG (1998) Climate variations and changes in mass of three glaciers in western North America. J Climate $11: 2161-2179$

Howe HF, Brown JS (2000) Early effects of rodent granivory on experimental forb communities. Ecol Appl 10:917-924

Jones CC (2003) Colonization limitation during primary succession on the foreland of Coleman Glacier. PhD Dissertation, University of Washington, Seattle, Washington, USA Jones CC, del Moral R (2005a) Effects of microsite conditions on seedling establishment on the foreland of Coleman Glacier, Washington. J Veg Sci 16:293-300

Jones CC, del Moral R (2005b) Patterns of primary succession on the foreland of Coleman Glacier, Washington, USA. Plant Ecol 180:105-116

Jumpponen A, Mattson K, Trappe JM, Ohtonen R (1998) Effects of established willows on primary succession on Lyman Glacier forefront, North Cascade Range, Washington, U.S.A.: evidence for simultaneous canopy inhibition and soil facilitation. Arct Alp Res 30:31-39 
Jumpponen A, Väre H, Mattson KG, Ohtonen R, Trappe JM (1999) Characterization of 'safe sites' for pioneers in primary succession on recently deglaciated terrain. J Ecol 87:98-105

Kartesz JT (1999) A synonymized checklist and atlas with biological attributes for the vascular flora of the United States, Canada, and Greenland. In: Kartesz JT, Meacham CA (eds) Synthesis of the North American flora, Version 1.0. North Carolina Botanical Garden, Chapel Hill, North Carolina, USA

Lichter J (2000) Colonization constraints during primary succession on coastal Lake Michigan sand dunes. J Ecol 88:825-839

Lindgren A, Eriksson O, Moen J (2007) The impact of disturbance and seed availability on germination of Alpine vegetation in the Scandinavian mountains. Arct Antarct Alp Res $39: 449-454$

Maron JL, Simms EL (2001) Rodent-limited establishment of bush lupine: field experiments on the cumulative effect of granivory. J Ecol 89:578-588

Matthews JA (1992) The ecology of recently-deglaciated terrain: A geoecological approach to glacier forelands and primary succession. Cambridge University Press, Cambridge, UK

Matthews JA, Whittaker RJ (1987) Vegetation succession on the Storbreen glacier foreland, Jotunheimen, Norway: a review. Arct Alp Res 19:385-395

McCune B, Keon D (2002) Equations for potential annual direct incident radiation and heat load. J Veg Sci 13:603-606

Menard S (2002) Applied logistic regression analysis, 2nd edn. Sage Publications, Thousand Oaks, California, USA 
Nathan R, Muller-Landau HC (2000) Spatial patterns of seed dispersal, their determinants and consequences for recruitment. Trends Ecol Evol 15:278-285

Niederfriniger Schlag R, Erschbamer B (2000) Germination and establishment of seedlings on a glacier foreland in the central Alps, Austria. Arct Antarct Alp Res 32:270-277

Oswald BP, Neuenschwander LF (1993) Microsite variability and safe site description for western larch germination and establishment. Bull Torrey Bot Club 120:148-156

Peterson DL (1994) Recent changes in the growth and establishment of subalpine conifers in western North America. In: Beniston M (ed) Mountain environments in changing climates. Routledge, London and New York, pp 234-243

Primack RB, Miao SL (1992) Dispersal can limit local plant distribution. Conserv Biol 6:513-519

R Development Core Team (2008) R: A language and environment for statistical computing. R Foundation for Statistical Computing, Vienna, Austria. ISBN: 3-900051-07-0, http://www.R-project.org

Reader RJ (1997) Potential effects of granivores on old field succession. Can J Bot $75: 2224-2227$

Rose R, Chachulski CEC, Haase DL (1998) Propagation of Pacific Northwest native plants. Oregon State University Press, Corvallis, Oregon, USA

Stevens MH, Bunker DE, Schnitzer SA, Carson WP (2004) Establishment limitation reduces species recruitment and species richness as soil resources rise. J Ecol 92:339-347

Tappeiner JC, Alaback PB (1989) Early establishment and vegetative growth of understory species in the western hemlock - Sitka spruce forests of southeast Alaska. Can J Bot $67: 318-326$ 
Titus JH, del Moral R (1998) Seedling establishment in different microsites on Mount St. Helens, Washington, USA. Plant Ecol 134:13-26

Turnbull LA, Crawley MJ, Rees M (2000) Are plant populations seed-limited? A review of seed sowing experiments. Oikos 88:225-238

Walker LR, Chapin FS (1987) Interactions among processes controlling successional change. Oikos 50:131-135

Walker LR, del Moral R (2003) Primary succession and landscape restoration. Cambridge University Press, Cambridge, UK

Walther GR, Beissner S, Burga CA (2005) Trends in the upward shift of alpine plants. J Veg Sci 16:541-548

Wilson DE, Reeder DM (eds) (2005) Mammal species of the world. A taxonomic and geographic reference, 3rd edn. Johns Hopkins University Press, Baltimore, Maryland, USA Wood DM, del Moral R (1987) Mechanisms of early primary succession in subalpine habitats on Mount St. Helens. Ecology 68:780-790

Young JA, Young CG (1992) Seeds of woody plants in North America. Dioscorides Press, Portland, Oregon, USA

Zolbrod AN, Peterson DL (1999) Response of high-elevation forests in the Olympic Mountains to climatic change. Can J For Res 29:1966-1978 
Table 1 Characteristics and pre-germination treatment of planted species. Nomenclature follows

Kartesz (1999)

Species

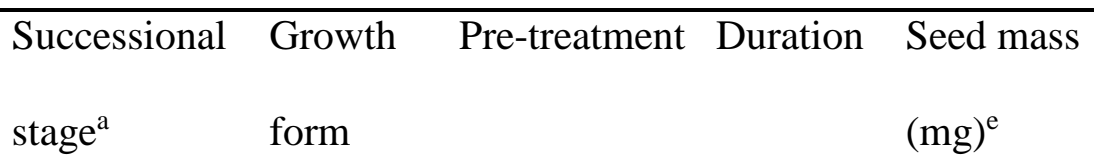

Abies amabilis

All

Tree

Cold-moist ${ }^{\mathrm{b}}$

30 days

38.6

Chamerion latifolium

Pioneer

Herb None

0.13

Ribes lacustre

Mid-seral

Shrub

Cold-moist $^{\mathrm{b}} \quad 90$ days

1.1

Sambucus racemosa

Mid-seral

Shrub

Cold-moist ${ }^{\mathrm{b}}$

90 days

2.5

Rubus spectabilis

Late-sera

Shrub

Warm/cold ${ }^{\mathrm{c}}$

90 days

2.8

Tiarella trifoliata

Late-sera

Herb

Cold-moist $^{\mathrm{b}} \quad 30$ days

0.36

Vaccinium ovalifolium

Late-seral

Shrub

$\mathrm{N} / \mathrm{A}^{\mathrm{d}}$

0.27

$\overline{{ }^{\mathrm{a}} \mathrm{All}}=$ present in all age classes; Pioneer = present in Age Class I but not Age Classes III and IV;

Mid-seral = first present in Age Class II; Late-seral = only present in Age Classes III and IV (from Jones 2003; Jones and del Moral 2005b).

${ }^{\mathrm{b}}$ Cold-moist stratification at $2-5^{\circ} \mathrm{C}$.

${ }^{\mathrm{c}}$ Warm-moist stratification $\left(21^{\circ} \mathrm{C}\right)$ for 30 days then cold-moist stratification for 60 days.

${ }^{\mathrm{d}}$ Vaccinium was planted only in October plots and did not receive any pre-treatment ${ }^{\mathrm{e}}$ From Jones (2003) 
Table 2. Results of generalized linear mixed models for July plots. Models were simplified using AIC. Values are estimated parameters using Poisson errors and a log link. No variables were retained in the model for Chamerion (not shown)

\begin{tabular}{lccccc}
\hline & Abies & Ribes & Rubus & Sambucus & Tiarella \\
\hline Model AIC & 67.43 & 82.68 & 107.3 & 27.14 & 119.6 \\
Intercept & -0.11 & -0.67 & $1.75^{* * *}$ & $-2.17^{* * *}$ & $2.13^{* * *}$ \\
Exclosure & -1.63 & 0.54 & -0.12 & & -0.17 \\
Seeding & 0.59 & $19.35^{* * *}$ & $21.08^{* * *}$ & $18.45^{* *}$ & $3.66^{* * *}$ \\
Age 1 & -18.88 & $4.27^{* *}$ & & & $-2.17^{*}$ \\
Age 2 & $-18.88^{* *}$ & 0.12 & $-1.88^{* *}$ & & $-2.86^{* * *}$ \\
Age 3 & $<0.001$ & & 0.48 & & 0.49 \\
Exclosure * Seeding & 1.46 & & & & \\
Exclosure * Age 1 & 20.49 & $-1.51^{* * *}$ & & & \\
Exclosure * Age 2 & $19.57^{* *}$ & & $1.34^{*}$ & & \\
Exclosure * Age 3 & $3.43^{* *}$ & & & & \\
Seeding * Age 1 & & & & & \\
Seeding * Age 2 & & & & & \\
Seeding * Age 3 & & & & & \\
\hline
\end{tabular}

Significance is based on z-scores from the Wald statistic. For large parameter estimates the Wald statistic is biased (Menard 2002); thus significance for estimates in italics is based on Chi-square comparison of models with and without the variable. ${ }^{*} 0.05>P>0.01 ; * * 0.01>P>0.001$;

$* * * P<0.001$ 
Table 3. Results of generalized linear mixed models for October plots. Models were simplified using AIC. Values are estimated parameters using Poisson errors and a log link.

\begin{tabular}{|c|c|c|c|c|c|c|c|}
\hline & Abies & Chamerion & Ribes & Rubus & Sambucus & Tiarella & Vaccinium \\
\hline Model AIC & 166 & 62.2 & 41.77 & 88.4 & 26.79 & 82.52 & 85.53 \\
\hline Intercept & $-2.46 * * *$ & $-4.24 * *$ & -21.87 & $-1.89 * * *$ & $-4.19 * * *$ & 0.61 & -0.39 \\
\hline Exclosure & $2.03^{* * *}$ & & $19.15^{* * *}$ & $0.60 * *$ & & $-2.6 *$ & $0.84 *$ \\
\hline Seeding & -0.59 & $19.31^{* * *}$ & $2.30 *$ & $4.47 * * *$ & $18.82 *$ & $2.53 * * *$ & $2.59 * * *$ \\
\hline Age 1 & $3.88 * * *$ & 1.68 & $20.75 * *$ & & & 0.66 & $-18.34 * * *$ \\
\hline Age 3 & $2.45 * * *$ & 2.96 & 1.92 & & & NA & -0.82 \\
\hline Exclosure * Seeding & $1.92 * * *$ & & & & & -1.91 & \\
\hline Exclosure $*$ Age 1 & $-4.16^{* * *}$ & & $-38.91^{*}$ & & & & \\
\hline Exclosure * Age 3 & & & & & & NA & \\
\hline Seeding * Age 1 & $0.40 * * *$ & & & & & $17.14^{*}$ & \\
\hline Seeding * Age 3 & 1.19 & $-20.22 * * *$ & & & & NA & \\
\hline
\end{tabular}

${ }^{*} 0.05>P>0.01 ; * * 0.01>P>0.001 ;{ }^{* * *} P<0.001$. For other details see Table 2 
Table 4. Spearman rank correlations of plot variables with number of seedlings per plot. Species abbreviations are as follows (ABAM=Abies amabilis, EPLA=Epilobium latifolium, RILA=Ribes lacustre, RUSP=Rubus spectabilis, SARA=Sambucus racemosa, TITR=Tiarella trifoliata, VAOV=Vaccinium ovalifolium). No correlations were siginificant for soil moisture or slope.

\begin{tabular}{|c|c|c|c|c|c|}
\hline & Age Class I & Age Class II & Age Class III & \multicolumn{2}{|c|}{ Age Class IV } \\
\hline Elevation & & RILA $\quad-0.68^{*}$ & EPLA -0.38* & RILA & $-0.49 * *$ \\
\hline Heat Load & RUSP $-0.84^{* *}$ & & & & \\
\hline Organic Matter & & ABAM $-0.70^{*}$ & & EPLA & $-0.37 *$ \\
\hline \multirow[t]{2}{*}{ Soil pH } & EPLA $0.70 *$ & & RUSP $0.38 *$ & RILA & $0.52 * *$ \\
\hline & & & & RUSP & $0.62 * *$ \\
\hline \multirow[t]{2}{*}{ Understory Cover } & & & RUSP $-0.44^{*}$ & RILA & $-0.43 *$ \\
\hline & & & TITR $-0.71^{*}$ & SARA & $-0.40 *$ \\
\hline \multirow[t]{3}{*}{ Canopy Cover } & & & EPLA $-0.49 * *$ & EPLA & $-0.42 *$ \\
\hline & & & & RILA & $-0.40 *$ \\
\hline & & & & RUSP & $-0.43^{*}$ \\
\hline
\end{tabular}

$* 0.05>p>0.01 ; * * p<0.01$ 


\section{Figure Captions}

Fig. 1 The Coleman Glacier foreland. Roman numerals identify age classes (see Study site) and lines indicate the position of the glacier in (from bottom up) 1823, 1908, and 1979. Roman numerals indicate approximate location of experimental plots

Fig. 2 Numbers of seedlings in July plots. Bars indicate the difference in numbers of seedlings between seeded plots and associated controls. Error bars indicate $\pm 1 \mathrm{SE}$

Fig. 3 Numbers of seedlings in October plots. Bars indicate the difference in numbers of seedlings between seeded plots and associated controls. Error bars indicate \pm 1 SE. No seeds of Tiarella were sown in Age Class III.

Fig. 4 Realized seed limitation (RSL) by species and age class. RSL is calculated as (1-density in controls/density in seed plots). NA indicates that RSL could not be calculated either because no seeds were planted (Vaccinium: Age Class II) or no seeds germinated. RSL for Chamerion in Age Class II was -0.75 because more seedlings were present in controls than seed plots

Fig. 5 Fundamental establishment limitation (FEL) by species and age class. FEL is calculated as (1 - mean density in seed plots/ maximum density in seed plots) following Nathan and MullerLandau (2000). NA indicates that FEL could not be calculated either because no seeds were planted (Vaccinium: Age Class II) or no seeds germinated 
Fig. 2

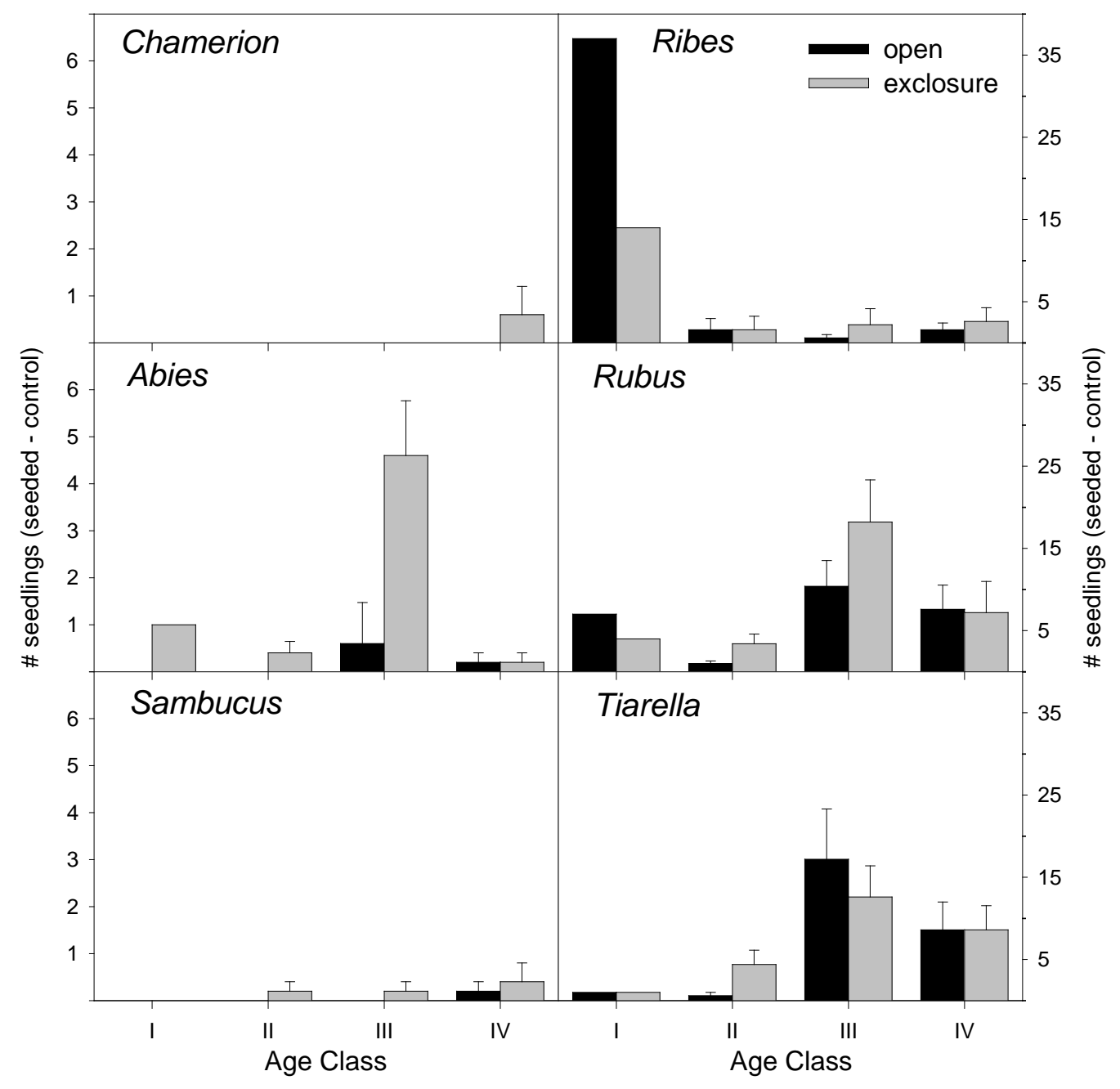


Fig. 3

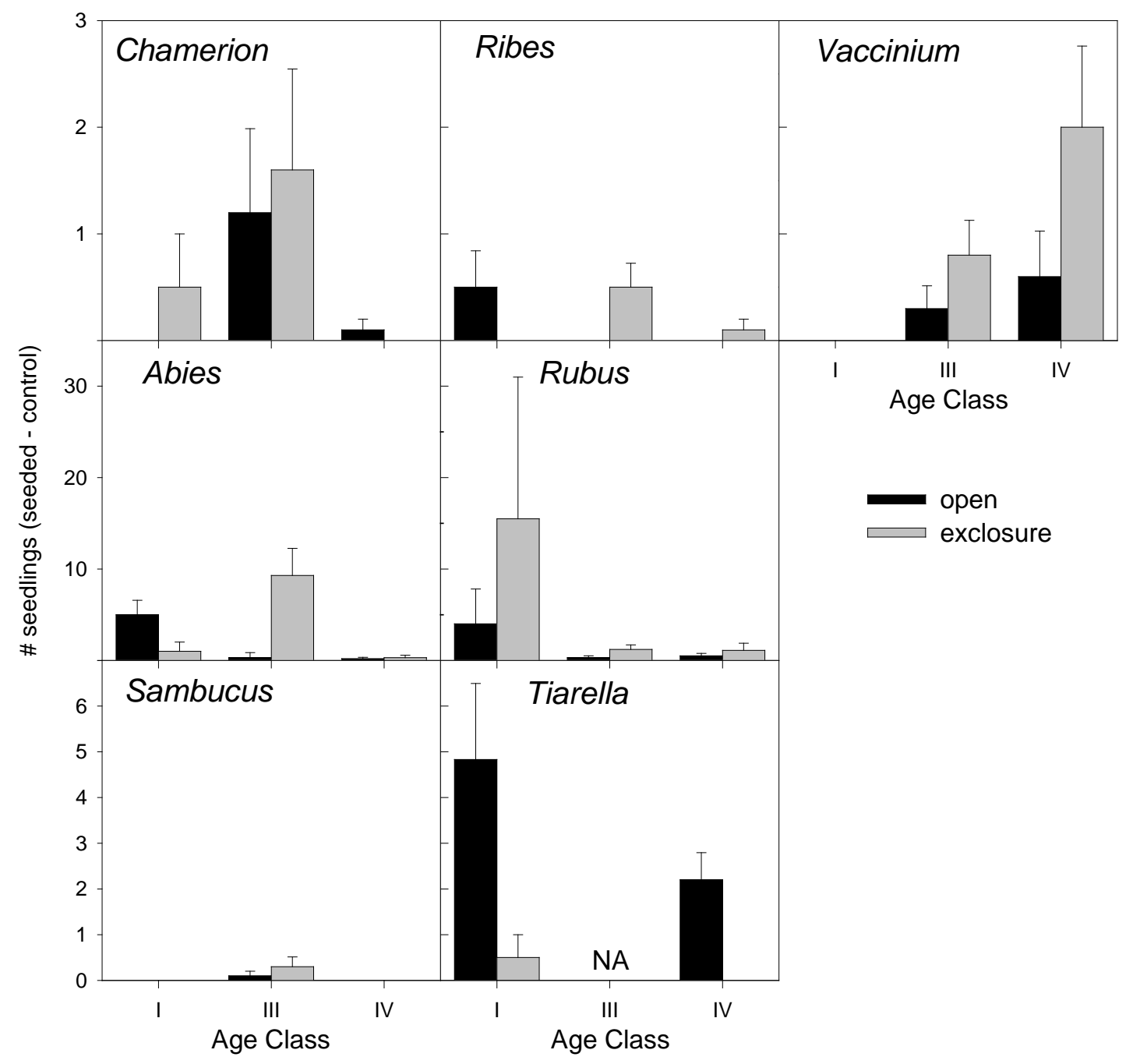


Fig. 4
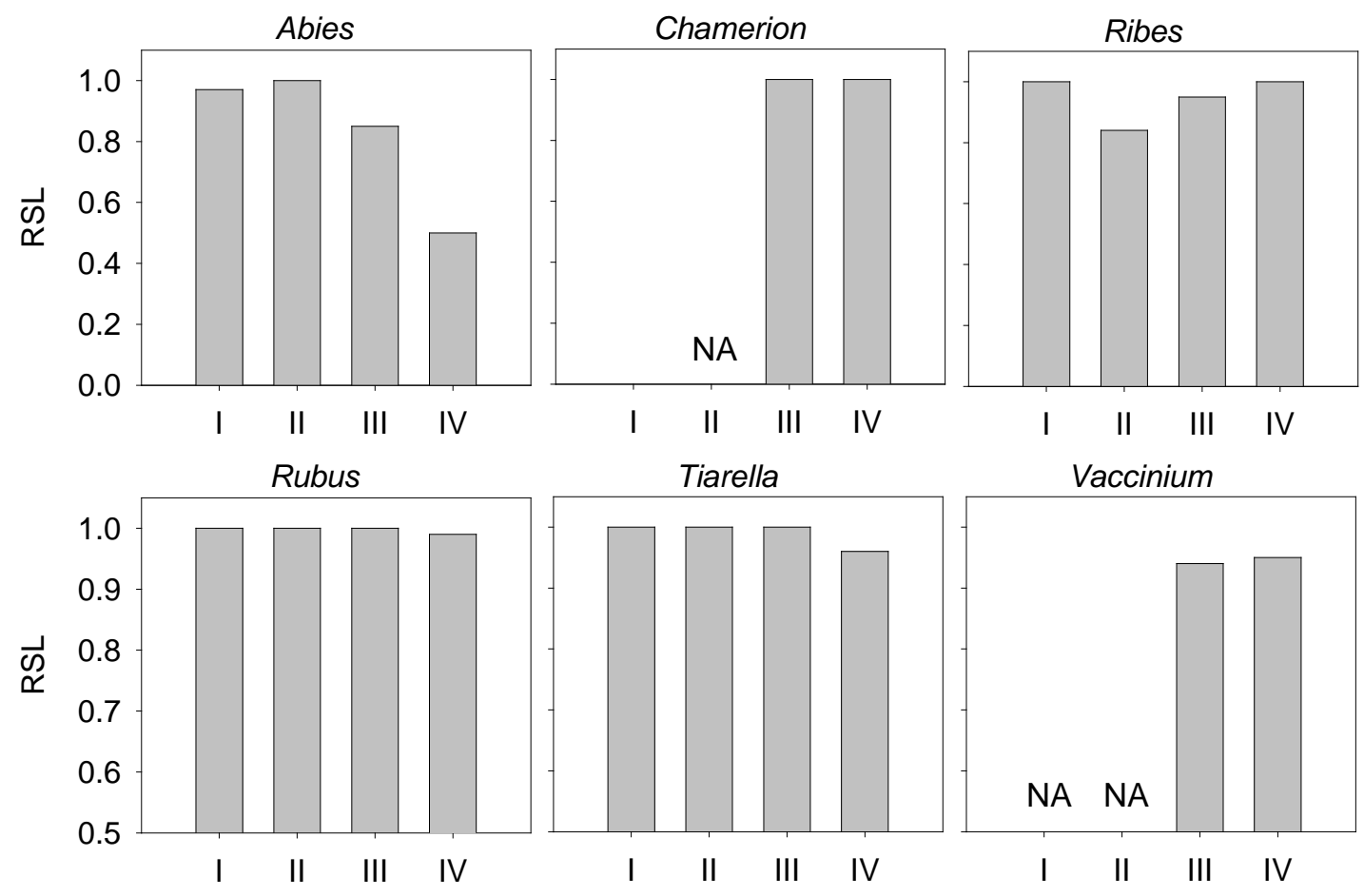
Fig. 5
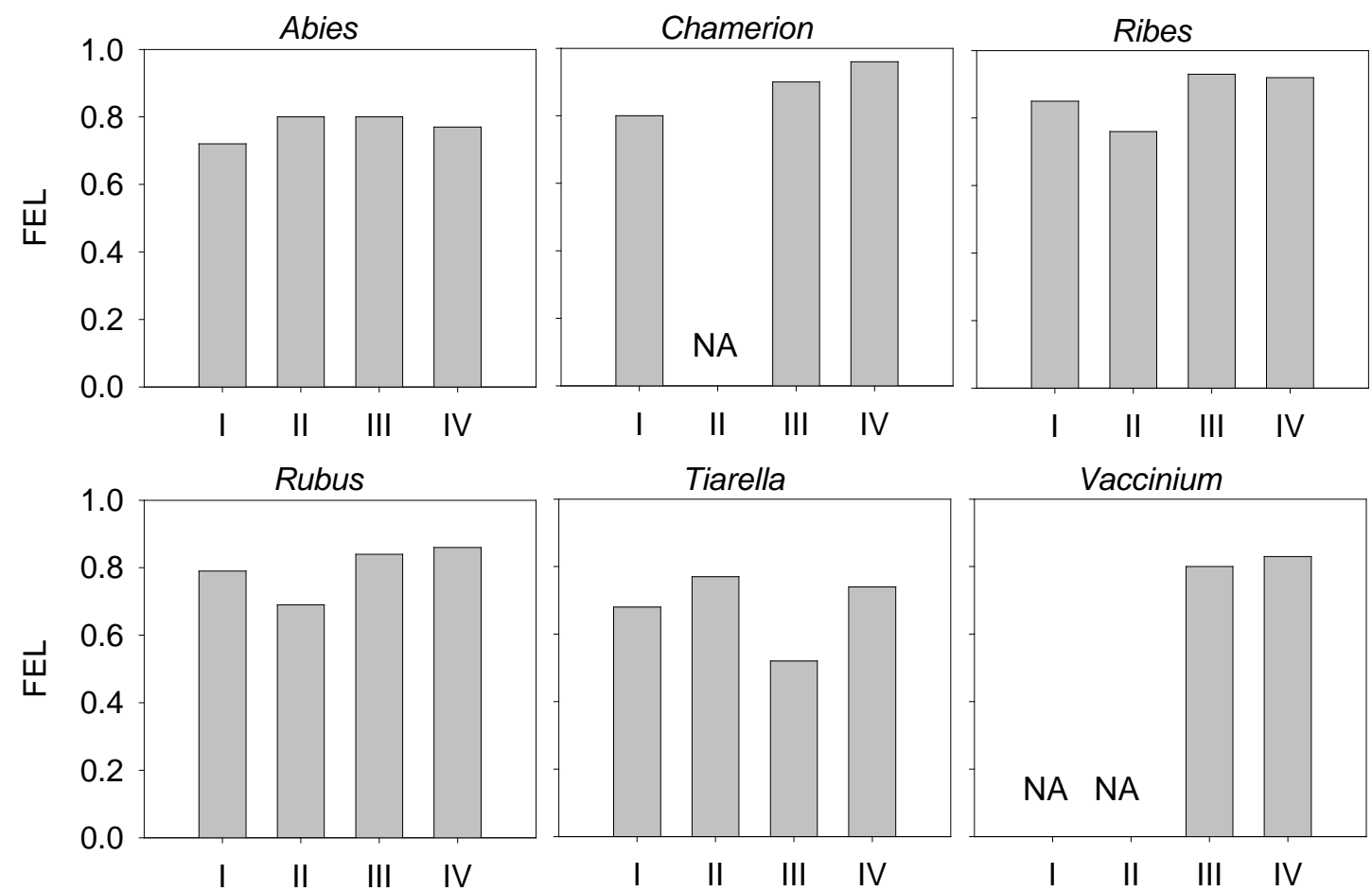